\title{
Dying while living: a critique of allowing-to-die legislation
}

\author{
Marc Lappé Office of Health, Law and Values, California Department of Health
}

Several US states are enacting 'right-to-die' laws, in the wake of the Karen Quinlan case. But the way such a law is drafted may cast doubt on a patient's existing common law right to control all aspects of his own treatment; it may give legal sanction to a lower standard of medical care that society at present expects from doctors; and it may lead to conflict between the patient's directive and his doctor's clinical judgement which cannot readily be resolved.

The laws themselves are categorised as a) legalising active killing or b) defining rights of patients to control treatment or c) assigning to others the rights to control treatment where the patient is not competent. The California law is discussed critically. The conclusion is that such legislation is not a satisfactory answer to the ethical problem of euthanasia.

Legislation to permit individuals to direct the conditions for their own terminal care has become so commonplace as to blunt our sensibilities to the original rationale for legal action, and more importantly, to minimise our willingness to criticise the desirability of such laws. Fully 85 different legislative acts have been proposed or acted on within the United States, and more may be expected. Forty-two states had bills in 1977, 12 of which carried over to this year. Florida and Michigan have prefiled for 1978, and seven states, Arkansas, Idaho, Nevada, New Mexico, North Carolina, Oregon and Texas, have had acts signed into law in 1977. All presume to place a person's final medical care, in some degree or in entirety, within the discretionary judgement of the terminally ill individual. 'Living Wills' or other so-called directives have proliferated to the point that virtually every new Act has a chapter specifying the language for a 'directive' of one kind or another.

Ironically, the Karen Ann Quinlan case which was the impetus for so much of the current legislation was resolved in a way which no contemporary allowing-to-die legislation would permit. As may be recalled, the Court directed a highly personalised and cumbersome decision in favour of Karen's parents: Karen was to be evaluated by a contingent of attending physicians; if the physicians concurred that there existed no reasonable possiblity of her ever emerging from her comatose condition to a cognitive, sapient state, the physicians were to consult a hospital ethics committee; if the ethics $\overrightarrow{0}$ committee agreed with the physicians, the attending physician was free to withdraw her life-support $\vec{\omega}$ system. Her parents, of course, after much terrible agony had agreed to this course. Their daughter $\overparen{\curvearrowright}$ was, in fact, weaned from her respirator almost two years ago. Yet, against every imagined possibility, and to her parents' continuing agony, Karen Ann $\mathcal{C}$ Quinlan still 'lives' today. How did we create such a 윽 living horror, a constant reminder of the banality of the evil which our technology can create? What $\square$ legislation might obviate similarly undesirable outcomes?

Ostensibly, the answers are relatively simple: Karen should never been allowed to reach the point of desperate and total dependency. No medical practitioner should have treated her heroically once the initial steps to encourage recovery failed. The mindless application of technology to the braininjured person beyond all hope of recovery is simply poor medical practice. Yet, our technology makes such a course inevitable.

As Professor Julius Korein, a neurologist testifying in the Quinlan case observed:

You've got a set of possible lesions that prior to the era of advance technology and advances in medicine were no problem ... the patient would expire ... I don't know how many years ago they couldn't keep a person alive with intravenous feedings because they couldn't give enough calories. Now they have these high caloric tube feedings that can keep people in excellent nutrition for years... Technology has now reached a point where you can in fact start to replace anything outside of the brain to maintain something that is irreversibly damaged.

What then about legislation to minimise the likelihood of more Karen Quinlans ? I do not think legislation is the answer. A reading of the case law makes it clear that with the exception of patients who are rendered incompetent by their injuries or disease process, persons in this country have a $\stackrel{\mathcal{D}}{\rightarrow}$ complete set of prerogatives to direct their terminal $T$ care in the absence of any permissive legislation.

I believe that most allowing-to-die legislation is ill-conceived, inappropriate, unnecessary and destructive to the very rights and prerogatives which it seeks to protect. Specifically, by conferring only incomplete power to patients for medical \section{.}


decisions affecting their final care, allowing-to-die legislation has unintentionally eroded at least three critical legal and cultural norms.

\section{Erosion of the right-to-refuse treatment}

First, by tacitly accepting that a patient does not have the complete prerogative to direct his or her own medical care, allowing-to-die legislation creates a dangerous legal precedent which did not previously exist. Until such legislation is in place, patients have and continue to have the absolute authority to direct the time, place and manner of their medical treatment subject to the rules of institutionalisation and the procedural guidelines of informed consent. No physician can intubate, catheterise or otherwise treat a conscious patient against that person's will.

Where a patient is considered to have a poor prognosis without treatment, a good chance of recovery with such treatment, and the treatment is not deemed essential, the right of a patient to refuse treatment has been upheld. [Erickson v. Dilgard. 44 Misc. 2d. 27, 252 N.Y.S.2d. 705 (Sup. Ct. I962); In re Nemser, 51 Misc. 2d. 51 Misc. 2d. 616, 273 N.Y.S.2d. 1964, (Sup. Ct. 1966).]

Even in an emergency situation, where death would ensue if treatment were not administered, the court, in In re Estate of Brooks, upheld a patient's refusal of treatment. [32 III. 2d. 36r, 205 N.E.2d. 435 (1965).]

Where death is inevitable despite any proposed treatment, the court refused to order surgery for a 72-year-old woman. [In Palm Springs General Hospital, Inc. v. Martinez, Civil No. 7I-12687 (Dade Co. Cir. Ct., filed July 2, I97I)]. In this case, medical procedures might have prolonged her life, but there was no hope of a cure. The patient had "begged her family not to 'torture me any more' with further surgery" [Washington Post July 5, I97I at I, Column I.] The Court stated:

Based upon [her] physical condition ... and the fact that performance of surgery ... and the administration of further blood transfusions would only result in the painful extension of her life for a short period of time, it is not in the interest of justice for this Court of Equity to order that she be kept alive against her will. [Palm Springs Gen. Hosp., Inc. v. Martinez, supra, citing Erickson v. Dilgard, supra at 27 and 705.]

Thus, the final and perhaps most compelling arguments of Karen's parents' attorneys, Paul Armstrong and James Crowley, was that Karen could have lawfully discontinued such treatment if she were competent. The Court must have also considered Karen's alleged expression of not wanting to be kept alive if she were severely damaged, an assertion which Karen repeated to witnesses no fewer than three times prior to her demise.
The Quinlan case, for better or worse, created the $\stackrel{\Pi}{+}$ public climate for legislation and inadvertently reinforced the conviction that only through a? Living Will or some other such directive can $\underset{\text { (N) }}{\vec{F}}$ person's wishes be respected should he become terminally ill.

Rather than being borne out by legislative action, $\frac{\bar{O}}{\sqrt{n}}$ that expectation has become almost a charade. $\mathbb{D}$ Virtually none of the legislation currently contemplated or enacted gives the patient discretionary $y^{\infty}$ authority to determine the actual nature and course $\vec{\circ}$ of his terminal treatment.

Most legislation, in fact, reinforces a form of medical paternalism. The AMA House of Delegates adopted a declaration in December of 1973 which $D$ epitomises the attitude of physicians with regard to patient discretion. The Council declared that while 'physicians may and indeed should be encourageder to discuss death and terminal illness with patients'o ... and that they 'may and indeed should respectexpressions of patient's wishes regarding medicall care during terminal illness' they emphasise that the physician 'should feel free to question those wishes 3 with patient's competent legal representative or byd appropriate judicial proceedings ...'

There is another possible pitfall in legalising medical directives. Allowing-to-die legislation is ${ }^{\infty}$ intended to permit a patient to make just those determinations which he would be incapable tos make should he be terminally ill by virtue of his enfeebled condition. True enough: but with the rare exception of the comatose patient, it is preciselyo the unprecedented psychological and emotional calamity of enfeeblement which morally dictates 3 extreme caution in giving a person the prerogative? to issue a directive which me may not be able tơ rescind should he later become incapable of com municating.

\section{Deterioration of standards of care}

Consider this little known but relatively common situation: a condition known as the 'locked-in'음 syndrome in which brain-injured persons are other- $\rightarrow$ wise conscious, but incapable of communicating their wishes.

Take a moment to contemplate the directions which you would give your physician for your own terminal care - think about them for just a minute ... . W Perhaps you indicated that you would not want? extraordinary care performed; or if you had someo evidence of brain damage, that artificial supports not be sustained past a certain critical point - or the use of ${ }^{?}$ antibiotics be contraindicated should you contract $D$ pneumonia.

Now, perform the mental exercise of discovering $\stackrel{\mathbb{D}}{\overparen{D}}$ yourself in a hospital bed, with only the jagged $\stackrel{\mathbb{Q}}{\Omega}$ memory of a night out, perhaps with some heavyo drinking and now you are just conscious of a doctor's presence, hovering at your bedside. You응 
discover that you cannot talk or move your arms or legs, but that you are perfectly conscious of every act or step in the room. You can hear them speaking. "What did you find in the wallet, nurse?"

"Well, Dr Sims, we have a uniform donor card here, and a Living Will as well as a Blue Cross card." "What does the will say ?"

"It says that 'no extraordinary means are to be used to treat me,' and wait, here is something else: it says that 'in the event that I am anoxic and unconscious for more than four minutes, or unable to communicate, that no artificial means of ventilation are to be used to sustain me."

"Well, that's clear enough in this case. Any evidence of hepatic failure or drug damage to the liver ?"

"No, doctor."

"Have the parents been contacted ?"

"We can't find any way of reaching them, doctor."

"Well, I have Mrs Kindred in terminal renal failure, and this man is obviously brain-damaged beyond the hope of full recovery. Why don't we hold off any further extraordinary therapy ? We have three cardiacs waiting for the ICU."

"OK, Dr Sims." Then you hear the sudden silence as machinery is shut off.

Now, the previous scenario may seem fanciful, but with a Living Will providing exoneration for neglect and giving compelling legal force to respecting a person's directives, $\mathrm{Dr}$ Sims might well be within his legal prerogatives to withhold treatment from you.

Thus, my second point is that the Living Will makes possible a standard of care which would not have been possible under previous legally enforced standards of medical practice.

\section{Creation of adversarial relationships}

The Living Will potentially creates an adversarial relationship between doctor and patient by giving some person's directive, made prior to contact with his treating physician, authority over the discretionary judgement of a physician. Moreover, since no person's directive can be overturned by relatives or a court (though this remains to be tested), the physician may well decide that he or she will refuse to treat anyone who has directed the terms of his own care without opportunity for consultation or a fair presentation of alternatives.

What then do present legislative efforts accomplish?

Medical ethicist Robert Veatch of the Institute of Society, Ethic and Life Sciences has reviewed the present spate of legislation. He finds that the bills presently being considered fall into three general categories:

I) Bills which would apparently legalise active killing;
2) Bills which would itemise the rights of competent patients to accept or refuse treatment; and

3) Bills which would assign the locus of decision making to other persons where the patient is incompetent.

The case I cited might have been sanctioned as the result of legislation introduced in Idaho in 1969 and Montana and Oregon in 1973. These bills would permit a doctor to 'euthanise' a patient whom he deemed beyond all hope of recovery of meaningful functions and humanhood. All refer to 'the administration of euthanasia' and implicity seem to authorise even active killing beyond the mere passive allowing-to-die characteristic of the remaining legislation. Veatch emphasises that such legislation is clearly out of step with the mainstream, and against public judgement. Nonetheless, it indicates how easily such legislation can corrupt public mores.

\section{The California Natural Death Act reconsidered}

The wave of legislation which would permit a competent patient to refuse treatment which he considered to be unnecessary or diminishing to his human worth began with legislation introduced in Wisconsin in 1971. It culminated in the first confirmed legal act in any state, the California Natural Death Act. I lobbied against this act with Karen Lebacqz, a bioethicist in the Office of Health, Law and Values. We tried to convince Governor Brown that the Act did not truly accomplish what it was intended to do: It did not provide assurance that if a person were to write something now it would have the legal force to assure that someone would follow his directions later. Indeed, the Natural Death Act, through its several amendments, appreciably undercut its original intent. It states that 'If the declarant becomes a qualified patient subsequent to executing the directive, and has not subsequently re-executed the directive, the attending physician may give weight, (but) ... may consider other factors such as information from affected family of the nature of the patient's illness, injury or disease, in determining whether the totality of circumstances known to the attending physician justify effectuating the directive.'

Ironically, under our present law, Karen Ann Quinlan could not have authorised the stopping of her own respirator, even if she had completed a directive in accordance with the law. Most disturbingly, the California Act may even deprive individuals of certain already existing rights to refuse medical treatment. In California today, one does not have any assurance that treatment will be discontinued in the weight of a directive based on the Living Will which is being distributed to literally thousands of concerned citizens. That prerogative, 
in fact, would probably have been recognised prior to the introduction of Keene's legislation, but it specifically does not have the force of law now.

Consider a second major flaw in our present legislation: the definition of 'terminal illness' is unnecessarily exclusive of just those conditions which the average citizen might hope he has been vouchsafed. A terminal illness is one which is 'caused by injury, disease, or illness which, regardless of the application of life-sustaining procedures, would, within reasonable medical judgement, produce death, and where the application of life-sustaining procedures serves only to postpone the moment of death of the patient.' Treatment could thus not be legally terminated until such time as death is, in fact, imminent (a difficult, if not impossible, judgement).

Such a definition excludes those very situations where treatment refusal is normally acceptable: for instance, the person in chronic kidney failure who is receiving agonising haemodialysis - precisely because, though critically ill, the person will not become terminal until several days have elapsed following withdrawal of dialysis.

The major flow with California's legislation is that it undermines the very principle which-right-to-dielegislation is intended to uphold to the greatest extent: patient autonomy. By denying the right to terminate treatment to all but the very most terminally ill person, it excludes the right to elect conditions for treatment for those for whom death is not imminent. In contrast, the Alabama legislature introduced a bill in 1976 which would permit a person to specify conditions which are consonant with his own moral and religious beliefs. The Alabama bill does not limit its applicability to conditions where the patient will die regardless of the treatment proferred: instead, it offers any 'individual over the age of nineteen the prerogative of instructing any physician to cease or refrain from medical or surgical treatment during possible prestated future states of competency as long as such demands do not result in undue harm to society as judged by court decision.' In this last sense, the Alabama bill, of all those offered in the US, comes closest to recognising the critical problem of all allowing-to-die legislation.

No legislation should be accepted unless it accords with the fundamental beliefs of the persons affected by it. In a pluralistic society that end is difficult at best. Unless every piece of allowing-todie legislation provides for the law to be checked constantly against the legal benchmark of society's basic institutions, it opens the door to undue rigidity and abuse. Society needs to grapple with the weighty problems of the dying patient. But legislation can be a smokescreen for the real problems of the dying patient: inadequate care, incomplete treatment and the shameful absence of loving and caring persons at the bedside.
Citations from In the Matter of Karen Quinlan,

No right is held more sacred, or is more carefull $\vec{F}$ guarded, by the common law, than the right of every individual to the possession and control of his own person: free from all restraint or interference of others, unless b clear and unquestionable authority of law Union Pacifis Railway Company v. Botsford, I4I U.S. 250, 25 I (I89I p. 13 .

"it seems correct to say there is no constitutional right t $\vec{\oplus}$ choose to die ... nor is a constitutional right established by adding that one's religious faith ordains his death"్ fohn F. Kennedy Memorial Hospital v. Heston, 58 N. at 580. p. 16-17.

Where a patient is considered to have a poor prognosis without treatment, a good chance of recovery with such treatment, and the treatment is not deemed essential, the right of a patient to refuse treatment has been upheld Erickson v. Dilgard, 44 Misc. 2d. 27, 252 N.Y. S.2d. 705 (Sup. Ct. 1962); In re Nemser, 51 Misc. 2d. 616, 273 N.Y.S. 2d. 1964 (Supp. Ct. 1966). p. 17.

I) 'At bottom then, the Cruel and Unusual Punish ments Clause prohibits the infliction of uncivilised and inhuman punishments. The State, even as it punishes, must treat its members with respect for their intrinsice worth as human beings. A punishment is "cruel an ${ }^{\circ}$ unusual", therefore, if it does not comport with humaro dignity.' at 270.

2) 'The primary principle is that a punishment muse not be so severe as to be degrading to the dignity of human beings.'

3) '[T]he State must not arbitrarily inflict a sever尺 punishment. This principle derives from the notion tha $\overrightarrow{5}$ the State does not respect human dignity when, withouB reason, it inflicts upon some people a severe punishmene that it does not inflict upon others.'

4) 'A third principle inherent in the Clause is that severe punishment must not be unacceptable to con temporary society. Rejection by society, of course, is a strong indication that a severe punishment does no $\mathrm{B}$. comport with human dignity.'

5) 'The final principle inherent in the Clause is that severe punishment must not be excessive. A punishment is excessive under this principle if it is unnecessary: The infliction of severe punishment by the State cannot comport with human dignity when it is nothing more than pointless infliction of suffering.' at 271, 274, 277 and 279.

I-5 above: By $\mathrm{Mr}$ Justice Brennan in Furman v.N Georgia, 408 U.S. 238 (1972) pp. 25-26.

'Life is explicitly protected by the Due Process Clause of the Fifth and Fourteenth Amendments.' U.S. Const.fo Amends. V, XIV. See N.J. Const., Art. I., para. I. p. 65.

Bibliography and notes

Meyers, David W (1977) The California Natural Death $\frac{\vec{C}}{\mathrm{C}}$ Act: A Critical Appraisal, California State Bar fournal, July/August pp. 326-383.

Jonsen, A (1978). Dying Right in California, Clinicalo Research, 26, 55-60.

Garland, $M$ (1976). The Right to Die in California, $\delta$ Hastings Center Report, 6, 5-7. 
Lebacqz, K (1977). Against the California Natural Death Act. Hastings Center Report, 7, I4-15.

Strand, J G (1976) The Living Will: The Right to Death With Dignity, Case Western Reserve Law Review, 26, no. 2, Winter pp. 485-526.

Orbon, M J (1976) The Living Will - An Individual's Exercise of His Rights of Privacy and Self-Determination, Loyola-University of Chicago Law fournal, 7, no. 3, Summer pp. 714-732.

Turner, J C (1976) Living Wills - Need for Legal Recognition, West Virginia Law Review, 78, no. 3, May, pp. 370-380.

(1976) "The Tragic Choice: Termination of Care for Patients in a Permanent Vegetative State, New York University Law Review, 51, no. 2, May, pp. 285-310.

Brown, R H and Truitt R B, (1976) Euthanasia and the Right to Die, Ohio Northern University Law Review, III, no. 3, pp. 615-642.

Kaplan, R P (1976) Euthanasia Legislation: A Survey and a Model Act, American fournal of Law and Medicine, 2, no. I, Summer, pp. 4I-99

Delgado, R (I975) Euthanasia Reconsidered: The Choice of Death as an Aspect of the Right of Privacy, in Symposium on Law and the Aged, Arizona Law Review, 17, no. 2, pp. 474-494.
Kapner, E (1975) Proposed State Euthanasia Statutes: A Philosophical and Legal Analysis, Hofstra Law Review, 3, Winter, pp. II5-140.

Cole, $S \mathrm{~S}$ and Shea, $M$ S Voluntary Euthanasia: $A \underset{\vec{N}}{\vec{F}}$ Proposed Remedy, Albany Law Review, 39, no. 4, pp. 826-856.

Symposium Issue. (1975) Euthanasia, Baylor Law Revierw, 27, no. I, Winter, pp. I-I73.

Montange, C H (1974) Informed Consent and the $\triangle$ Dying Patient, Yale Law fournal, 83, no. 8, July, क pp. I632-1664.

Vaughan, N L (1974) Right to Die, California Western Law Review, 10, no. 3, Spring, pp. 613-627.

Forkosch, MD Privacy, Human Dignity, Euthanasia Are These Independent Constitutional Rights? University of San Fernando Valley Law Review, 3, no. 2, pp. I-25

Smyth, J A (1974) Antidysthanasia Contracts: A Proposal for Legalizing Death With Dignity, $\overrightarrow{0}$ Pacific Law fournal, 5, July, pp. 738-763.

Vodiga, B (1974) Euthanasia and the Right to Die-Moral, 은 Ethical and Legal Perspectives, Chicago-Kent Law Review, 51, no. I, Summer, pp. I-40.

Malone, Robert J Is There a Right to a Natural Death ? New England Law Review, 9, no. 293, pp. 308-309. 